\title{
Effects of Polyethylene Glycol on Bovine Intestine Alkaline Phosphatase Activity and Stability
}

\author{
Satoshi Sekiguchi, Kiyoshi Yasukawa, and Kuniyo Inouye ${ }^{\dagger}$ \\ Division of Food Science and Biotechnology, Graduate School of Agriculture, Kyoto University, \\ Sakyo-ku, Kyoto 606-8502, Japan
}

Received May 24, 2011; Accepted July 22, 2011; Online Publication, November 7, 2011

[doi:10.1271/bbb.110403]

In this study, we evaluated the effects of polyethylene glycol (PEG) on bovine intestine alkaline phosphatase (BIALP) activity and stability. In the hydrolysis of $p$-nitrophenylphosphate (pNPP) at $\mathrm{pH} 9.8$ at $20^{\circ} \mathrm{C}$, the $k_{\text {cat }} / K_{\mathrm{m}}$ values of BIALP plus $5-15 \% \mathrm{w} / \mathrm{v}$ free PEG with molecular masses of 1, 2, 6, and $20 \mathrm{kDa}$ (PEG1000, PEG2000, PEG6000, and PEG20000 respectively) were $120-140 \%, 180-300 \%, 130-170 \%$, and $110-140 \%$ respectively of that of BIALP without free PEG $\left(1.8 \mu M^{-1} s^{-1}\right)$, indicating that activation by PEG2000 was the highest. Unmodified BIALP plus 5\% PEG2000 and BIALP pegylated with 2,4-bis $(O$-methoxypolyethylene glycol)-6-chloro-s-triazine exhibited 1.3-fold higher activity on average than that of BIALP without free PEG under various conditions, including pH 7.0-10.0 and $20-65^{\circ} \mathrm{C}$. The temperatures reducing initial activity by $50 \%$ in 30-min incubation of unmodified BIALP plus 5\% PEG2000 and pegylated BIALP were 51 and $47^{\circ} \mathrm{C}$ respectively, similar to that of BIALP without free PEG $\left(49^{\circ} \mathrm{C}\right)$. These results indicate that the addition of PEG2000 and pegylation increase BIALP activity without affecting its stability, suggesting that they can be used in enzyme immunoassay with BIALP to increase sensitivity and rapidity.

Key words: alkaline phosphatase; bovine intestine alkaline phosphatase; enzyme immunoassay; pegylation; polyethylene glycol

Phosphatases (EC 3.1.3.1) catalyze the hydrolysis of phosphomonoesters. They are classified into two groups, as alkaline phosphatase (ALP) and acid phosphatase (ACP), depending on their optimal $\mathrm{pH}$ in alkaline and acidic $\mathrm{pH}$ regions respectively. ALPs are widely distributed in bacteria and mammals, and play essential roles in biochemical processes. ${ }^{1-4)}$ Their structural and functional properties are considered to be commonly conserved in all ALPs. ALP is a homodimeric metalloenzyme. The subunit has a molecular mass of about $50 \mathrm{kDa}$ and contains two $\mathrm{Zn}^{2+}$ ions and one $\mathrm{Mg}^{2+}$ ion. ${ }^{5,6)}$ The catalytic triad composed of the two $\mathrm{Zn}^{2+}$ and one $\mathrm{Mg}^{2+}$ ions is conserved in all ALPs, from Escherichia coli to mammals. ${ }^{7)}$ Mammalian ALP is present in the liver, intestine, placenta, kidney, and other tissues. The molecular activity $\left(k_{\text {cat }}\right)$ of mammalian ALP is 10 60 times higher than that of E. coli ALP. ${ }^{8)}$ Bovine intestine ALP (BIALP) has the highest specific activity among mammalian ALPs. It has been applied as a signaling enzyme in sensitive assays such as enzyme immunoassay (EIA), Western blotting analysis, nucleic acid hybridization assay, polymerase chain reaction, etc., and is used in diagnosis, immunology, and molecular biology. ${ }^{9-12)}$ Therefore, increase in the activity and stability of BIALP is an important subject for practical use. We have found that amines and aminoalcohols activate BIALP. ${ }^{13)}$

Polyethylene glycol (PEG) is a hydrophilic, biocompatible polymer. The covalent attachment of PEG to proteins (pegylation) is effective for advanced clinical uses. It drastically increases the serum half lives of therapeutic proteins administered to humans and decreases their immunogenicity. Pegylated adenosine deaminase $^{14)}$ and asparaginase ${ }^{15)}$ have been approved for human use by the US Food and Drug Administration, but the effects of pegylation and the external addition of free PEG on the in vitro uses of enzymes have not well been described. In this study, we examined the effects of the external addition of free PEG and pegylation on BIALP activity and stability.

\section{Materials and Methods}

Materials. BIALP (lot 13609227) was purchased from Roche Diagnostics (Basel, Switzerland). The preparation was used without further purification. 2,4,6-Trinitrobenzenesulfonic acid (TNBS) (lot ALN6692) was from Wako Pure Chemical (Osaka, Japan). p-Nitrophenyl phosphate (pNPP) (lot M9T3188) and monomethoxy PEG of 1, 2, 6, and 20kDa (PEG1000, PEG2000, PEG6000, and PEG20000 respectively) were from Nacalai Tesque (Kyoto, Japan). The concentration of pNPP was determined spectrophotometrically using the molar absorption coefficient, $\varepsilon_{310}$, of $10,380 \mathrm{M}^{-1} \mathrm{~cm}^{-1}$. $^{13)} 2$,4-Bis $(O-$ methoxypolyethylene glycol)-6-chloro-s-triazine (10 kDa) (mPEG) was from Seikagaku (Tokyo). BIALP-conjugated goat anti-rabbit IgG antibody was from Santa Cruz Biotechnology (Santa Cruz, CA). All other chemicals were of reagent grade and were purchased from Nacalai Tesque or Wako Pure Chemical.

Preparation of pegylated BIALP. Pegylation of BIALP was accomplished by adding solid mPEG $(160 \mathrm{mg})$ to $2.0 \mathrm{~mL}$ of 2.0 $\mathrm{mg} / \mathrm{mL}$ of BIALP in $50 \mathrm{~mm}$ borate- $\mathrm{NaOH}, 1.0 \mathrm{mM} \mathrm{MgCl}_{2}$, and $20 \mu \mathrm{M}$ $\mathrm{ZnCl}_{2}$ at $\mathrm{pH} 10.0$. The reaction mixture was maintained at $20^{\circ} \mathrm{C}$ for $2 \mathrm{~h}$ with continuous stirring and subjected to Amicon Ultra YM-30 (Amicon, Bedford, MA) using $30 \mathrm{mM}$ triethanolamine- $\mathrm{HCl}, 3.0 \mathrm{M}$ $\mathrm{NaCl}, 1.0 \mathrm{~mm} \mathrm{MgCl}_{2}$, and $100 \mu \mathrm{M} \mathrm{ZnCl}_{2}$ at $\mathrm{pH} 7.6$ at $4{ }^{\circ} \mathrm{C}$ to remove unbound $\mathrm{mPEG}$.

\footnotetext{
$\dagger$ To whom correspondence should be addressed. Tel: +81-75-753-6266; E-mail: inouye@kais.kyoto-u.ac.jp

Abbreviations: ALP, alkaline phosphatase; BIALP, bovine intestine alkaline phosphatase; EIA, enzyme immunoassay; PEG, polyethylene glycol; pNPP, $p$-nitrophenyl phosphate; TNBS, 2,4,6-trinitrobenzenesulfonic acid
} 
The degree of pegylation of the amino groups of BIALP was evaluated using TNBS. ${ }^{16,17)}$ Briefly, solid TNBS (5.5 mg) was dissolved in $1.0 \mathrm{~mL}$ of $0.4 \mathrm{mg} / \mathrm{mL}$ of unmodified, pegylated BIALPs in $50 \mathrm{~mm}$ borate- $\mathrm{NaOH}, \mathrm{pH}$ 9.0. The reaction mixture was maintained at $25^{\circ} \mathrm{C}$ for $2 \mathrm{~h}$ with continuous stirring and was dialyzed against the same buffer to remove unbound TNBS. The number of amino groups modified with TNBS was spectrophotometrically determined from the absorbance at $280 \mathrm{~nm}, A_{280}$, and at $344 \mathrm{~nm}, A_{344}$, using the following equations:

$$
\begin{aligned}
& A_{280}=50500 t+3300 n \\
& A_{344}=10900 n
\end{aligned}
$$

where $t$ and $n$ represent the molar concentrations of total BIALP and the amino groups modified with TNBS, respectively. An $\varepsilon_{280}$ of $50,500 \mathrm{M}^{-1} \mathrm{~cm}^{-1}$ was used for unmodified BIALP according to the numbers of Tyr and Trp residues in one BIALP molecule (19 and 4 respectively), ${ }^{18)}$ an $\varepsilon_{280}$ of $1,490 \mathrm{M}^{-1} \mathrm{~cm}^{-1}$ for $\mathrm{Tyr}$, and an $\varepsilon_{280}$ of $5,500 \mathrm{M}^{-1} \mathrm{~cm}^{-1}$ for Trp. An $\varepsilon_{344}$ of $10,900 \mathrm{M}^{-1} \mathrm{~cm}^{-1}$ was used for TNBS-modified amino groups. ${ }^{16,17)}$ The number of pegylated amino groups was calculated by the difference in the numbers of TNBSmodified amino groups of the pegylated and unmodified BIALPs.

SDS-PAGE. SDS-PAGE was performed in a $10 \%$ polyacrylamide gel under reducing conditions by the method of Laemmli. ${ }^{19)}$ Proteins were reduced by treatment with $2.5 \%$ of 2 -mercaptoethanol at $100{ }^{\circ} \mathrm{C}$ for $10 \mathrm{~min}$, and then applied onto the gel. A constant current of $40 \mathrm{~mA}$ was applied for $60 \mathrm{~min}$. After electrophoresis, the proteins were stained with Coomassie Brilliant Blue R-250. A molecular mass marker kit consisting of pig myosin $(200 \mathrm{kDa}), E$. coli $\beta$-galactosidase $(116 \mathrm{kDa})$, rabbit muscle phosphorylase $\mathrm{B}(97.2 \mathrm{kDa})$, bovine serum albumin $(66.4 \mathrm{kDa})$, hen egg-white ovalbumin $(44.3 \mathrm{kDa})$, and bovine carbonic anhydrase $(29.0 \mathrm{kDa})$ was purchased from Takara Bio. (Otsu, Japan).

Hydrolysis of pNPP. BIALP-catalyzed hydrolysis of pNPP was initiated by mixing $2,990 \mu \mathrm{L}$ of the substrate solution in $1.0 \mathrm{M}$ diethanolamine- $\mathrm{HCl}, 1.0 \mathrm{mM} \mathrm{MgCl}_{2}$, and $20 \mu \mathrm{M} \mathrm{ZnCl}_{2}$ at $\mathrm{pH} 9.8$ pre-incubated at $20^{\circ} \mathrm{C}$ and $10 \mu \mathrm{L}$ of $12 \mathrm{nM}$ BIALP solution, unless otherwise specified. The initial enzyme and substrate concentrations were $40 \mathrm{pm}$ and $0.1-4.0 \mathrm{~mm}$ respectively. The reaction was carried out at $20^{\circ} \mathrm{C}$ and was measured by following the increase in absorbance at $405 \mathrm{~nm}, A_{405}$, for 3 min with a Jasco V-550 spectrophotometer (Jasco, Tokyo). The product, $p$-nitrophenol, was estimated using the molar absorption difference due to hydrolysis, $\Delta \varepsilon_{405}=17,500 \mathrm{M}^{-1} \mathrm{~cm}^{-1}$, at $\mathrm{pH} 9.8$ at $20^{\circ} \mathrm{C}^{20)}$ The kinetic parameters, the molecular activity, $k_{\text {cat }}$, and the Michaelis constant, $K_{\mathrm{m}}$, were calculated from the Hanes-Woolf equation (eq. 3) by least-squares regression.

$$
\frac{1}{v_{0}}=\frac{K_{\mathrm{m}}}{V_{\max }[\mathrm{S}]_{0}}+\frac{1}{V_{\max }}
$$

In this equation, $v_{0}, V_{\max }$, and $[\mathrm{S}]_{0}$ are the initial reaction rate, the maximal initial reaction rate, and the initial substrate concentration respectively. The value of $k_{\text {cat }}$ was calculated from $V_{\max }$ using a monomer molecular mass of $50 \mathrm{kDa}$.

Irreversible thermal inactivation of BIALP. BIALP (1.25 nM) in $1.0 \mathrm{M}$ diethanolamine- $\mathrm{HCl}, 1.0 \mathrm{mM} \mathrm{MgCl}_{2}$, and $20 \mu \mathrm{M} \mathrm{ZnCl}$ at $\mathrm{pH} 9.8$ was incubated at a set temperature for $30 \mathrm{~min}$ and subsequently incubated at $20^{\circ} \mathrm{C}$ for $3 \mathrm{~min}$. The remaining activity of BIALP in pNPP hydrolysis was determined at $20^{\circ} \mathrm{C}$, as described above.

\section{Results}

Effects of the addition of free PEG on BIALP activity First we examined the effects of the addition of $1-15 \% \mathrm{w} / \mathrm{v}$ free PEG with molecular masses of 1, 2, 6, and $20 \mathrm{kDa}$ (PEG1000, PEG2000, PEG6000, and PEG20000 respectively) on BIALP activity in the hydrolysis of $0.1-4.0 \mathrm{~mm} \mathrm{pNPP}$ at $20^{\circ} \mathrm{C}$. The $\mathrm{pH}$ was set to 9.8 based on previous reports. ${ }^{21-23)}$ Figure 1 shows the dependences of $v_{0}$ of BIALP with $5 \%$ free PEG on the pNPP concentration. All the plots showed saturated

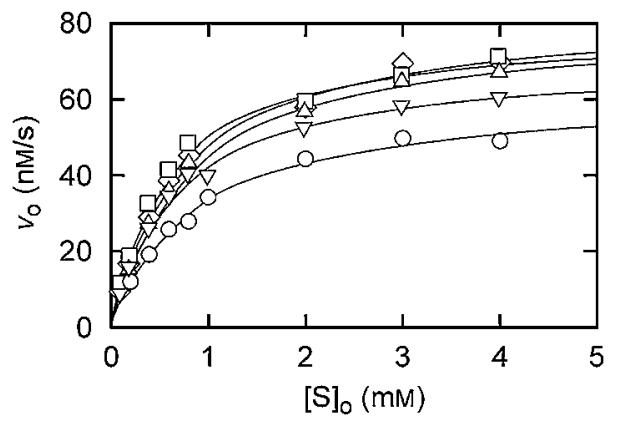

Fig. 1. Dependence of the Initial Reaction Rate on the pNPP Concentration.

The pNPP-hydrolysis reaction was carried out with $40 \mathrm{pM}$ BIALP in $1.0 \mathrm{M}$ diethanolamine- $\mathrm{HCl}, 1.0 \mathrm{mM} \mathrm{MgCl}_{2}, 20 \mu \mathrm{M} \mathrm{ZnCl}_{2}$, and various concentrations of PEGs at $\mathrm{pH} 9.8$ at $20^{\circ} \mathrm{C}$. The initial reaction rates, $v_{0}$, are plotted against the $\mathrm{pNPP}$ concentration. Solid line represents the best fit of the Michaelis-Menten equation using the nonlinear least-squares methods. Symbols for the enzymes:

$\bigcirc$, BIALP without free PEG; $\triangle$, BIALP plus 5\% PEG1000;

$\square$, BIALP plus 5\% PEG2000; $\diamond$, BIALP plus 5\% PEG6000;

$\nabla$, BIALP plus $5 \%$ PEG20000.

profiles. The same profiles were obtained for 1,10 , and $15 \%$ free PEG (data not shown). Table 1 shows the $k_{\text {cat }}$, $K_{\mathrm{m}}$, and $k_{\text {cat }} / K_{\mathrm{m}}$ values of BIALP without and with $1-$ $15 \%$ free PEG. The $k_{\text {cat }}$ value of BIALP without free PEG was $1,440 \pm 30 \mathrm{~s}^{-1}$. The $k_{\text {cat }}$ values increased with increasing PEG1000, PEG2000, and PEG6000 concentrations, and reached maximum at 5\% for PEG1000 $\left(2,020 \pm 60 \mathrm{~s}^{-1}\right), 15 \%$ for PEG2000 $\left(2,020 \pm 90 \mathrm{~s}^{-1}\right)$, and $5 \%$ for PEG6000 $\left(2,080 \pm 90 \mathrm{~s}^{-1}\right)$, while they did not change much with increasing PEG20000 concentrations. The $K_{\mathrm{m}}$ values of BIALP without free PEG decreased with increasing PEG2000 concentrations and reached a minimum $(0.19 \pm 0.06 \mathrm{~mm})$ at $30 \%$, while they did not with increasing PEG1000, PEG6000, or PEG20000 concentrations. The $k_{\text {cat }} / K_{\mathrm{m}}$ values of BIALP plus 5-15\% PEG1000, PEG2000, PEG6000, and PEG20000 were 120-140\%, 180-300\%, 130-170\%, and $110-140 \%$ respectively of that of BIALP without free PEG. These results indicate that the addition of free PEG activates BIALP, and that the effect of PEG2000 is the highest. We used PEG2000 in subsequent analysis.

\section{Pegylation of BIALP}

Next we prepared pegylated BIALP. mPEG (Fig. 2A) is designed to bind to the N-terminal amino group and the $\varepsilon$-amino group of the Lys residue of a protein (Fig. 2B). Pegylation of BIALP was carried out at the $[\mathrm{mPEG}] /[\mathrm{BIALP}]$ ratio of $400: 1 \mathrm{~mol} / \mathrm{mol}$. The average number of TNBS-modified amino groups of the unmodified and pegylated BIALPs were 12 and four respectively. Hence it was calculated that eight out of 22 amino groups of monomeric BIALP were pegylated. The pegylated BIALP not subsequently modified with TNBS exhibited a UV absorption spectrum with a peak at $280 \mathrm{~nm}$, while that subsequently modified with TNBS exhibited a spectrum with peaks, at 280 and $344 \mathrm{~nm}$ (Fig. 2C). On SDS-PAGE under reducing conditions, unmodified BIALP exhibited a protein band corresponding to $50 \mathrm{kDa}$, while the pegylated BIALP exhibited a protein band corresponding to $200 \mathrm{kDa}$ at a rough estimate (Fig. 2D), which did not agree with the speculated molecular mass of the pegylated BIALP 
Table 1. Kinetic Parameters of BIALP in the Hydrolysis of pNPP

\begin{tabular}{|c|c|c|c|c|}
\hline & \multirow{2}{*}{$\begin{array}{c}{[\mathrm{PEG}]} \\
(\%, \mathrm{w} / \mathrm{v})\end{array}$} & \multicolumn{3}{|c|}{ Kinetic parameters } \\
\hline & & $k_{\text {cat }} \times 10^{-2}\left(\mathrm{~s}^{-1}\right)$ & $K_{\mathrm{m}}(\mathrm{mM})$ & $k_{\mathrm{cat}} / K_{\mathrm{m}}\left(\mu \mathrm{M}^{-1} \mathrm{~s}^{-1}\right)$ \\
\hline BIALP & & $14.4 \pm 0.3(1.0)$ & $0.79 \pm 0.03$ & $1.8 \pm 0.1(1.0)$ \\
\hline BIALP + PEG1000 & 1 & $15.8 \pm 0.4(1.1)$ & $0.62 \pm 0.04(0.8)$ & $2.5 \pm 0.1(1.4)$ \\
\hline BIALP + PEG1000 & 5 & $20.2 \pm 0.6(1.4)$ & $0.80 \pm 0.06(1.0)$ & $2.5 \pm 0.1(1.4)$ \\
\hline BIALP + PEG1000 & 10 & $17.9 \pm 0.5(1.2)$ & $0.74 \pm 0.04(0.9)$ & $2.4 \pm 0.1(1.3)$ \\
\hline BIALP + PEG1000 & 15 & $18.7 \pm 0.5(1.3)$ & $0.88 \pm 0.06(1.1)$ & $2.1 \pm 0.1(1.2)$ \\
\hline BIALP + PEG2000 & 1 & $16.9 \pm 0.4(1.2)$ & $0.69 \pm 0.06(0.9)$ & $2.4 \pm 0.1(1.2)$ \\
\hline BIALP + PEG2000 & 5 & $20.0 \pm 0.8(1.4)$ & $0.63 \pm 0.06(0.8)$ & $3.2 \pm 0.1(1.8)$ \\
\hline BIALP + PEG2000 & 10 & $18.8 \pm 0.5(1.3)$ & $0.43 \pm 0.03(0.5)$ & $4.4 \pm 0.1(2.4)$ \\
\hline BIALP + PEG2000 & 15 & $20.2 \pm 0.9(1.4)$ & $0.37 \pm 0.06(0.5)$ & $5.4 \pm 0.3(3.0)$ \\
\hline BIALP + PEG6000 & 1 & $16.7 \pm 0.4(1.2)$ & $0.60 \pm 0.04(0.8)$ & $2.8 \pm 0.1(1.6)$ \\
\hline BIALP + PEG6000 & 5 & $20.8 \pm 0.9(1.4)$ & $0.75 \pm 0.08$ & $2.8 \pm 0.1(1.6)$ \\
\hline BIALP + PEG6000 & 10 & $21.1 \pm 1.3(1.5)$ & $0.70 \pm 0.14(0.9)$ & $3.0 \pm 0.2(1.7)$ \\
\hline BIALP + PEG6000 & 15 & $21.3 \pm 1.4(1.5)$ & $0.89 \pm 0.14(1.1)$ & $2.4 \pm 0.2(1.3)$ \\
\hline BIALP + PEG20000 & 1 & $15.2 \pm 0.5(1.1)$ & $0.61 \pm 0.05(0.8)$ & $2.5 \pm 0.1(1.4)$ \\
\hline BIALP + PEG20000 & 5 & $17.6 \pm 0.4(1.2)$ & $0.66 \pm 0.03(0.8)$ & $2.6 \pm 0.1(1.4)$ \\
\hline BIALP + PEG20000 & 10 & $17.2 \pm 0.6(1.2)$ & $0.76 \pm 0.06(1.0)$ & $2.2 \pm 0.1(1.2)$ \\
\hline BIALP + PEG20000 & 15 & $15.1 \pm 0.6(1.1)$ & $0.81 \pm 0.09(1.0)$ & $1.9 \pm 0.1(1.1)$ \\
\hline
\end{tabular}

The reaction was carried out with an initial enzyme concentration of $40 \mathrm{pM}$ in $1.0 \mathrm{M}$ diethanolamine- $\mathrm{HCl}$ containing $1.0 \mathrm{mM} \mathrm{MgCl}_{2}, 20 \mu \mathrm{M} \mathrm{ZnCl}_{2}$ at $\mathrm{pH} 9.8$ at $20^{\circ} \mathrm{C}$. Numbers in parenthesis indicate values relative to unmodified BIALP without free PEG.

A

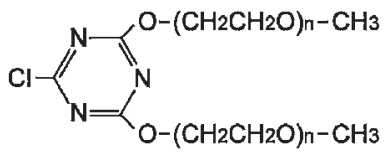

$\mathrm{C}$

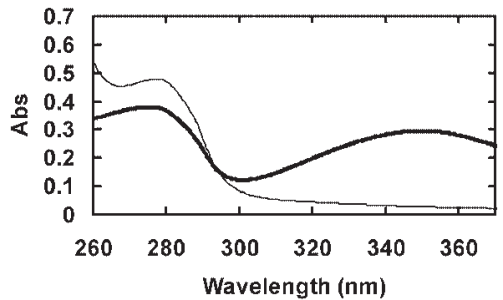

B<smiles>CCOCCOc1nc(N[GaH2])nc(OCCOCC)n1</smiles>

$\mathrm{D}$

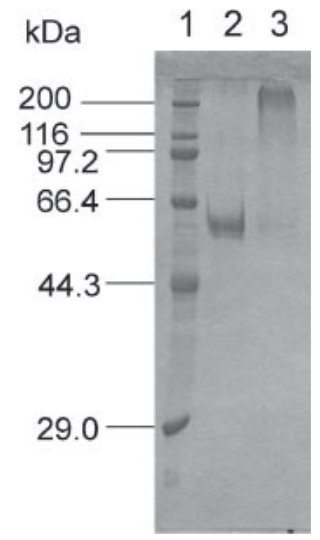

Fig. 2. Pegylation of BIALP with mPEG.

A, Molecular structure of mPEG. B, Molecular structure of the pegylated amino group. C, Absorption spectrum of the pegylated BIALP (thin line) and the TNBS-modified pegylated BIALP (bold line) in $30 \mathrm{~mm}$ triethanolamine- $\mathrm{HCl}, 3.0 \mathrm{M} \mathrm{NaCl}, 1.0 \mathrm{~mm} \mathrm{MgCl}_{2}$, and $100 \mu \mathrm{M} \mathrm{ZnCl} 2$ at pH 7.6. D, SDS-PAGE of BIALP under reducing conditions. Coomassie Brilliant Blue-stained $10 \%$ polyacrylamide gel is shown. Lane 1 , molecular-mass marker; lane 2, unmodified BIALP; and lane 3, pegylated BIALP.

$(130 \mathrm{kDa})$ comprising monomeric BIALP $(50 \mathrm{kDa})$ and eight $\mathrm{mPEG}$ molecules $(80 \mathrm{kDa})$. It is known that on SDS-PAGE, pegylated proteins exhibit a protein band of higher molecular mass than expected. ${ }^{24)}$ We used this preparation in subsequent analysis.

Effects of the addition of PEG2000 and pegylation on BIALP activity under various conditions

We examined the effects of the addition of PEG2000 and pegylation on BIALP activity under various conditions. Figure $3 \mathrm{~A}$ shows the $\mathrm{pH}$ dependences of $v_{0}$ of unmodified BIALP without and with 5\% PEG2000 and pegylated BIALP in the hydrolysis of pNPP at $20^{\circ} \mathrm{C}$. The initial pNPP concentration was set at $3 \mathrm{~mm}$, considerably higher than the $K_{\mathrm{m}}$ values of BIALP with 1-15\% PEG2000 (0.37-0.69 mM) (Table 1). Because the $k_{\text {cat }}$ values of BIALP with $1-15 \%$ PEG2000 were almost entirely stable $\left(1,690-2,020 \mathrm{~s}^{-1}\right)$ (Table 1$)$, the PEG2000 concentration was set at 5\%. Unmodified BIALP without free PEG showed profiles with an optimal $\mathrm{pH}$ of 8.5-9.5, which agreed well with previous reports. ${ }^{25-27)}$ Unmodified BIALP plus 5\% PEG2000 and pegylated BIALP showed the same profiles. The $v_{0}$ values at $\mathrm{pH} 9.0$ of unmodified BIALP plus $5 \%$ PEG2000 and pegylated BIALP were $86 \pm 2$ and $83 \pm 3 \mathrm{nM} / \mathrm{s}$ respectively, higher than of that of unmodified BIALP without free PEG $(64 \pm 2 \mathrm{nM} / \mathrm{s})$. These results indicate that the addition of PEG2000 and pegylation increased BIALP activity at $\mathrm{pH}$ 7.0-10.0.

Figure $3 \mathrm{~B}$ shows the temperature dependences of $v_{0}$ at $\mathrm{pH}$ 9.8. Measurements at $>65^{\circ} \mathrm{C}$ were not done due to the difficulty in preparing buffers at the corresponding temperatures. Unmodified BIALP showed an optimal temperature of $55-60^{\circ} \mathrm{C}$, which agreed well with a 

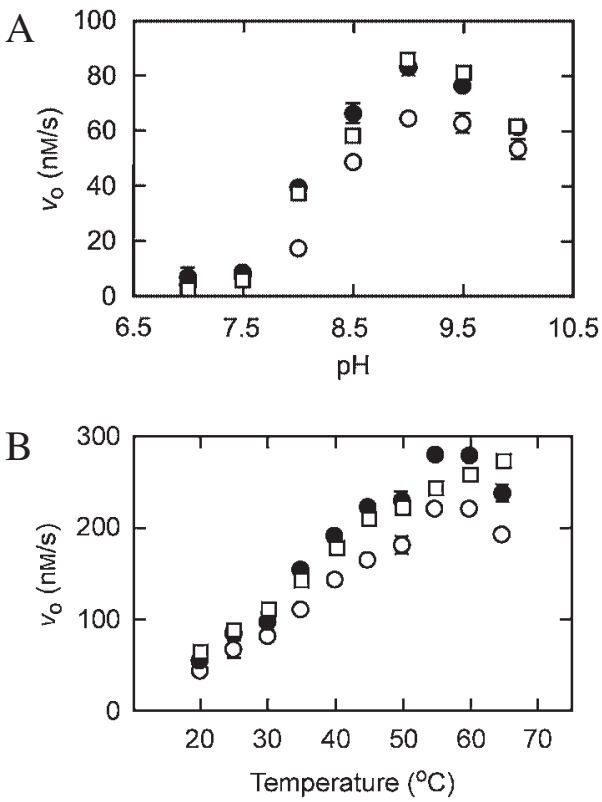

Fig. 3. Effects of Pegylation and the Addition of Free PEG on BIALP Activity.

The pNPP-hydrolysis reaction was carried out with 40 pM BIALP and $3 \mathrm{~mm}$ pNPP in $1.0 \mathrm{M}$ diethanolamine- $\mathrm{HCl}, 1.0 \mathrm{mM} \mathrm{MgCl}_{2}, 20 \mu \mathrm{M}$ $\mathrm{ZnCl}_{2}$. A, pH-dependence of $v_{0}$. The reaction was carried out at $20^{\circ} \mathrm{C}$. B, Temperature-dependence of $v_{0}$. The reaction was carried out at $\mathrm{pH}$ 9.8. Error bars indicate SD values of the triplicate determination. Symbols for the enzymes: $\bigcirc$, unmodified BIALP without free PEG; $\square$, unmodified BIALP plus 5\% PEG2000; $\bullet$, pegylated BIALP.

previous report. ${ }^{23)}$ The optimal temperature of pegylated BIALP was $55-60{ }^{\circ} \mathrm{C}$, and that of unmodified BIALP with $5 \%$ PEG2000 was $65^{\circ} \mathrm{C}$ or higher. The $v_{0}$ values at $55^{\circ} \mathrm{C}$ of unmodified BIALP with PEG2000 and of pegylated BIALP were $243 \pm 3$ and $278 \pm 2 \mathrm{nM} / \mathrm{s}$ respectively, higher than that of unmodified BIALP without free PEG $(219 \pm 2 \mathrm{nM} / \mathrm{s})$. These results indicate that the addition of PEG2000 and pegylation increased BIALP activity at $20-65^{\circ} \mathrm{C}$.

\section{Effects of the addition of PEG2000 and pegylation on} BIALP stability

We examined the effects of the addition of PEG2000 and pegylation on BIALP stability. BIALP was treated at various temperatures $\left(30-60^{\circ} \mathrm{C}\right)$ for $30 \mathrm{~min}$. Figure 4 shows the relative activity of heat-treated BIALP in the hydrolysis of pNPP. All the plots showed similar sigmoid curves. The temperatures required to reduce initial activity by $50 \%$ in $30 \mathrm{~min}, T_{50}$, of unmodified BIALP plus 5\% PEG2000 and pegylated BIALP were $51 \pm 1$ and $47 \pm 2{ }^{\circ} \mathrm{C}$ respectively, similar to that of unmodified BIALP without free PEG $\left(49 \pm 1^{\circ} \mathrm{C}\right)$. This indicates that neither the addition of PEG2000 nor pegylation affects BIALP stability.

Effects of the addition of PEG2000 on the activity of antibody-conjugated BIALP

To explore further the usefulness of the addition of PEG in EIA, we examined the effects of the addition of PEG2000 on the activity of antibody-conjugated BIALP. Figure $5 \mathrm{~A}$ shows the $\mathrm{pH}$ dependences of $v_{0}$ without and with 5\% PEG2000 in the hydrolysis of pNPP at $20^{\circ} \mathrm{C}$. Antibody-conjugated BIALP plus 5\% PEG2000

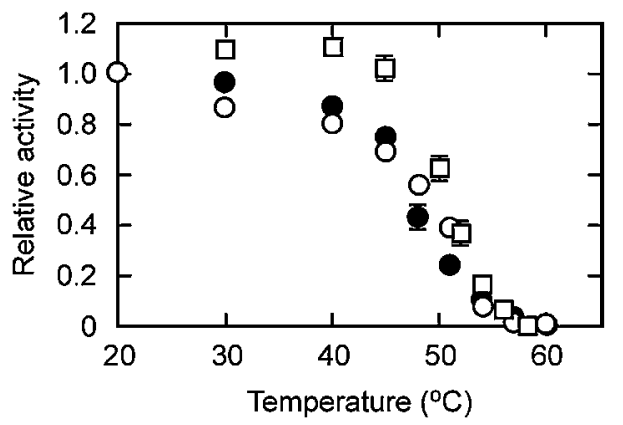

Fig. 4. Effects of Pegylation and the Addition of Free PEG on BIALP Stability.

The relative activity of BIALP for pNPP hydrolysis was defined as the ratio of $v_{0}$ with the $30 \mathrm{~min}$ of incubation at the temperatures indicated to that at $20^{\circ} \mathrm{C}$ (unmodified BIALP, $57 \pm 1 \mathrm{~nm} / \mathrm{s}$; BIALP plus $5 \%$ PEG2000, $64 \pm 3 \mathrm{~nm} / \mathrm{s}$; pegylated BIALP, $64 \pm 2 \mathrm{~nm} / \mathrm{s}$ ). Error bars indicate SD values of the triplicate determination. Symbols for the enzymes: $\bigcirc$, unmodified BIALP without free PEG; $\square$, unmodified BIALP plus 5\% PEG2000; 9 , pegylated BIALP.
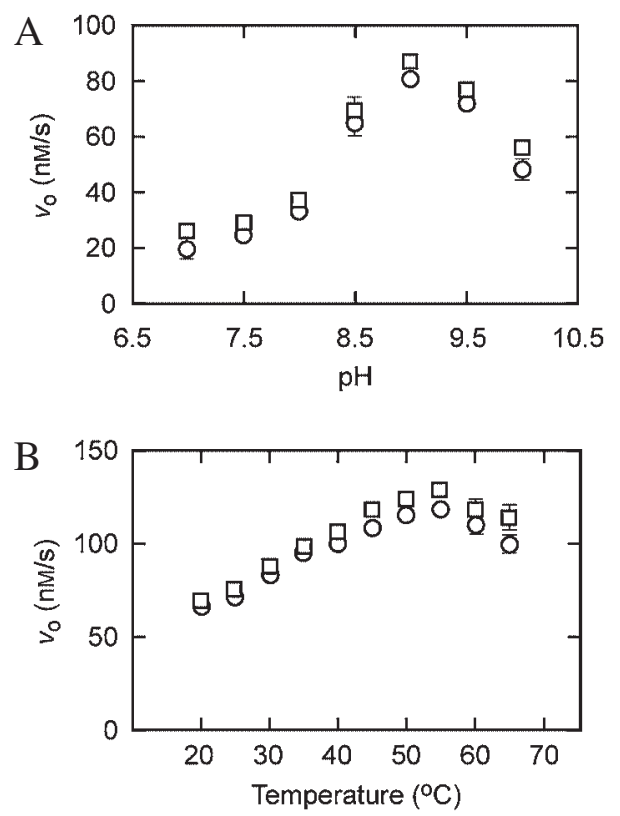

Fig. 5. Effects of the Addition of Free PEG on the Activity of Antibody-Conjugated BIALP.

The pNPP-hydrolysis reaction was carried out with $1 \mathrm{ng} / \mathrm{mL}$ of antibody-conjugated BIALP and $3 \mathrm{~mm}$ pNPP in $1.0 \mathrm{M}$ diethanolamine- $\mathrm{HCl}, 1.0 \mathrm{~mm} \mathrm{MgCl}_{2}, 20 \mu \mathrm{M} \mathrm{ZnCl}_{2}$. A, $\mathrm{pH}$-dependence of $v_{0}$. The reaction was carried out at $20^{\circ} \mathrm{C}$. B, Temperature-dependence of $v_{0}$. The reaction was carried out at $\mathrm{pH} 9.8$. Error bars indicate SD values of the triplicate determination. Symbols for the enzymes: $\bigcirc$, antibody-conjugated BIALP without free PEG; $\square$, antibody-conjugated BIALP plus 5\% PEG2000.

showed the same profile as that without free PEG. The $v_{0}$ value at $\mathrm{pH} 9.0$ of antibody-conjugated BIALP plus $5 \%$ PEG2000 was $87 \pm 1 \mathrm{nM} / \mathrm{s}$, higher than that of antibody-conjugated BIALP without free PEG $(79 \pm$ $1 \mathrm{nM} / \mathrm{s})$. This indicates that the addition of PEG2000 increases the activity of antibody-conjugated BIALP at $\mathrm{pH}$ 7.0-10.0. Figure 5B shows the temperature dependences of $v_{0}$ at $\mathrm{pH}$ 9.8. The optimal temperature of antibody-conjugated BIALP with and without $5 \%$ PEG2000 was $55^{\circ} \mathrm{C}$. The $v_{0}$ value at $55^{\circ} \mathrm{C}$ of antibody-conjugated BIALP plus 5\% PEG2000 was $130 \pm 1 \mathrm{nM} / \mathrm{s}$, higher than that of antibody-conjugated 
BIALP without free PEG $(118 \pm 1 \mathrm{~nm} / \mathrm{s})$. This indicates that the addition of PEG2000 increases the activity of antibody-conjugated BIALP at $20-65^{\circ} \mathrm{C}$.

\section{Discussion}

Activation of BIALP by the addition of free PEG and pegylation

The $\mathrm{pH}$ and temperatures for the reaction with BIALP in EIA vary depending on individual assay. For example, the $\mathrm{pH}$ and temperature were 9.5 and $37^{\circ} \mathrm{C}$ for the EIA for leptin, ${ }^{12)} 9.5$ and $30^{\circ} \mathrm{C}$ for the EIA for 1,2-dioxetane, ${ }^{28)} 9.5$ and $25^{\circ} \mathrm{C}$ for the EIA for thyroidstimulating hormone, ${ }^{29)}$ and 9.5 and $37^{\circ} \mathrm{C}$ for the EIA for $17 \beta$-oestradiol. ${ }^{30}$ ) In this study, under various conditions including $\mathrm{pH} 7.0-10.0$ and $20-65^{\circ} \mathrm{C}$, the addition of PEG2000 and pegylation increased the activity of BIALP by $30 \%$ on average (Fig. 3), and the addition of PEG2000 increased the activity of antibody-conjugated BIALP by $15 \%$ on average (Fig. 5). This suggests that the addition of PEG2000 and pegylation can be used in EIA to increase sensitivity and rapidity.

In EIA, the enzyme reaction velocity, $v_{0}$, is proportional to the initial enzyme concentration, $[\mathrm{E}]_{0}$, and the $k_{\text {cat }}$ of the enzyme according to the Michaelis-Menten equation. Therefore, high enzyme activity is favorable in order to get higher $v_{0}$ values. In other words, when the $k_{\text {cat }}$ of the signaling enzyme was increased, the sensitivity of EIA was enhanced, and thus the time needed to detect a signal of the product was reduced. In this study, the $k_{\text {cat }}$ values of the BIALP with 5-15\% PEG1000, PEG2000, and PEG6000 were $120-150 \%$ of that of unmodified BIALP without free PEG (Table 1), suggesting that the addition of PEG2000 is most effective in EIA.

In this study, no significant difference was observed between the effects of the addition of PEG2000 and those of pegylation on the activity and stability of BIALP, but the experimental conditions were substantially different. For example, in the hydrolyzing reaction with 40 pM BIALP, the concentration of PEG2000 was $5 \% \mathrm{w} / \mathrm{v}$, while the concentration of BIALP-bound PEG can be calculated to have been $320 \mathrm{pm}$ because the average number of bound PEG $(10 \mathrm{kDa})$ in one pegylated BIALP molecule was eight. Hence it cannot be concluded that there is no difference between the effects of the addition of PEG2000 and those of pegylation on the activity and stability of BIALP.

The mechanism of activation of BIALP by free PEG is unclear. Activation of BIALP by free PEG was brought about by increases in $k_{\text {cat }}$ rather than decreases in $K_{\mathrm{m}}$ (Table 1). Regarding this, we have examined the activation of the activity of thermolysin, a thermostable neutral metalloproteinase produced in the culture broth of Bacillus thermoproteolyticus, by neutral salts, and have reported that it is brought about by increases in $k_{\text {cat }}$, but not by decreases in $K_{\mathrm{m}} \cdot{ }^{31-33)}$ We have also examined the inhibition of the activities of neuraminidase, ${ }^{34)}$ thermolysin, ${ }^{35)}$ human matrix metalloproteinase 7 (MMP-7), ${ }^{36)}$ and Streptomyces caespitosus neutral protease $(\mathrm{ScNP})^{37)}$ by various alcohols. We speculate that not only the dielectric constant of the reaction medium but also the interaction between neutral salts or alcohols and particular surface sites of enzymes are involved in neutral salts-induced activation and alcohol-induced inhibition. ${ }^{31-37)}$ If this is the case for BIALP and the sites of BIALP to which PEG binds are identified, sitespecific pegylation might be effective. ${ }^{38)}$

\section{Effects of PEG on enzyme activity}

Effects on enzyme activities of the addition of free PEG and pegylation were not predicted. They are particular to the various enzymes and must be investigated on an individual basis. Chiu et al. reported that pegylation activates and stabilizes trypsin, although the mechanisms are not known. ${ }^{39)}$ In non-aqueous solution, pegylation increases the activities of various enzymes such as lipase ${ }^{40)}$ and subtilisin Carlsberg, ${ }^{41)}$ but in aqueous solution, it decreases the activities of various enzymes such as $\alpha$-chymotrypsin ${ }^{42)}$ and lysozyme. ${ }^{43)}$ In the case of $\alpha$-chymotrypsin, pegylation decreased the $k_{\text {cat }}$ values without changing the $K_{\mathrm{m}}$ values. ${ }^{44)}$ This decrease in $k_{\text {cat }}$ was explained by the fact that six out of 14 Lys residues of $\alpha$-chymotrypsin are located near the active site. ${ }^{39)}$ Gonnelli and Strambini found that pegylation did not affect the internal dynamics of ribonuclease T1, azurin, alcohol dehydrogenase, or E. coli ALP, as assessed by fluorescence from internal Trp residues. ${ }^{45)}$ Hence it can be said that pegylation does not decrease enzyme activities unless the amino acid residues to which PEG is linked are located at the active site.

The effects of pegylation on trypsin activity varied depending on the sizes of the conjugated PEGs. ${ }^{38,46)}$ In those studies, the $p$-nitroanilide hydrolysis activities of porcine pancreatic trypsin modified with 2,5 , or $10-\mathrm{kDa}$ PEG at 4-5 out of 11 amino groups of one trypsin molecule were about $120 \%$ of that of unmodified trypsin, while the activities of trypsin modified with $20-\mathrm{kDa}$ PEG were about $80 \%$ of that of unmodified trypsin. This is similar to our results, that the $k_{\mathrm{cat}} / K_{\mathrm{m}}$ values of BIALP plus 5-15\% PEG1000, PEG2000, PEG6000, and PEG20000 were 120-140\%, 180-300\%, $130-170 \%$, and $110-140 \%$ respectively of that of BIALP without free PEG (Table 1). Thus it can be said that the effects of the addition of free PEG and pegylation on enzyme activities depend on the size of PEG.

In conclusion, it is suggested that the addition of free PEG to and pegylation of BIALP can be used in EIA to increase sensitivity and rapidity. To elucidate the mechanisms, further study is required of the interaction between PEG and BIALP.

\section{References}

1) Reid TW and Wilson IB, "The Enzymes" 3rd ed. Vol. 4, ed. Boyer PD, Academic Press, New York, pp. 373-415 (1971).

2) Fernley HN, "The Enzymes" 3rd ed. Vol. 4, ed. Boyer PD, Academic Press, New York, pp. 417-447 (1971).

3) Kim EE and Wyckoff HW, J. Mol. Biol., 218, 449-464 (1991).

4) Harada $T$, Koyama I, Matsunaga $T$, Kikuno A, Kasahara $T$, Hashimoto M, Alpers DH, and Komoda T, FEBS J., 272, 24772486 (2005).

5) Stec B, Holtz KM, and Kantrowitz ER, J. Mol. Biol., 299, 13031311 (2000).

6) De Backer MME, McSweeney S, Lindley PF, and Hough E, Acta Cryst., D60, 1555-1561 (2004).

7) Gettins P and Coleman JE, J. Biol. Chem., 258, 408-416 (1983). 
8) Murphy JE, Tibbitts TT, and Kantrowitz ER, J. Mol. Biol., 253, 604-617 (1995).

9) Blake MS, Johnston KH, Russell-Jones GR, and Gotschlich EC, Anal. Biochem., 136, 175-179 (1984).

10) Jablonski E, Moomaw EW, Tullis RH, and Ruth JL, Nucleic Acids Res., 14, 6115-6128 (1986).

11) Chan DW, "Immunoassay," eds. Diamandis EP and Christopoulos TK, Academic Press, New York, pp. 483-504 (1996).

12) Sekiguchi S, Kohno H, Yasukawa K, and Inouye K, Biosci. Biotechnol. Biochem., 75, 752-756 (2011).

13) Sekiguchi S, Hashida Y, Yasukawa K, and Inouye K, Enzyme Microb. Technol., 49, 171-176 (2011).

14) Hershfiled MS, Clin. Immunol. Immunopathol., 76, S228-S332 (1995).

15) Zhang JF, Shi LY, and Wei DZ, Biotechnol. Lett., 26, 753-756 (2004).

16) Sashidar BRA, Capoor K, and Ramana D, J. Immunol. Methods, 167, 121-127 (1994).

17) Habeeb A, Anal. Biochem., 14, 328-336 (1965).

18) Manes T, Hoylaerts MF, Muller R, Lottspeich F, Holke W, and Millan JL, J. Biol. Chem., 273, 23353-23360 (1998).

19) Laemmli UK, Nature, 227, 680-685 (1970).

20) Inouye $K$, Tonomura $B$, Hiromi $K$, Sato $S$, and Murao S, J. Biochem., 82, 961-967 (1997).

21) Hoylaerts MF and Millan JL, Eur. J. Biochem., 202, 605-616 (1991).

22) Hoylaerts MF, Manes T, and Millan JL, Biochem. J., 286, 23-30 (1992).

23) Weissig H, Schildge A, Hoylaerts MF, Iqbal M, and Millan JL, Biochem. J., 290, 503-508 (1993).

24) Nojima Y, Iguchi K, Suzuki Y, and Sato A, Biol. Pharm. Bull., 32, 523-526 (2009).

25) Morton RK, Biochem. J., 60, 573-582 (1955).

26) Chappelet-Tordo D, Lazdunski $M$, Iwatsubo $M$, Gache $C$, and Lazdunski M, Biochemistry, 13, 1788-1795 (1974).
27) Angkawidjaja C, Kuwahara K, Omori K, Koga Y, Takano K, and Kanaya S, Protein Eng. Des. Sel., 19, 337-343 (2006).

28) Bronstein I, Edwards B, and Voyta JC, J. Biolumin. Chemilumin., 4, 99-111 (1989).

29) Morimoto K and Inouye K, J. Immunol. Methods, 205, 81-90 (1997).

30) Kokado A, Arakawa H, and Maeda M, Luminescence, 17, 5-10 (2002).

31) Inouye K, J. Biochem., 112, 335-340 (1992).

32) Inouye K, Kuzuya K, and Tonomura B, Biochim. Biophys. Acta, 1388, 209-214 (1998).

33) Inouye K, Kuzuya K, and Tonomura B, J. Biochem., 123, 847852 (1998).

34) Inouye K, Izawa S, Saito A, and Tonomura B, J. Biochem., 117, 629-634 (1995).

35) Muta Y and Inouye K, J. Biochem., 132, 945-951 (2002).

36) Oneda H, Muta Y, and Inouye K, Biosci. Biotechnol. Biochem., 68, 1811-1813 (2004).

37) Inouye K, Shimada T, and Yasukawa K, J. Biochem., 142, 317324 (2007).

38) Chiu K, Agoubi LL, Lee I, Limpar MT, Lowe Jr JW, and Goh SL, Biomacromolecules, 11, 3688-3692 (2010).

39) Inada Y and Matsushima A, Biocatalysis, 3, 317-328 (1990).

40) Castíllo B, Solá RJ, Ferrer A, Barletta G, and Griebenow K, Biotechnol. Bioeng., 99, 9-17 (2008).

41) Rodríguez-Martínez JA, Rivera-Rivera I, Solá RJ, and Griebenow K, Biotechnol. Lett., 31, 883-887 (2009).

42) So T, Ueda T, Abe Y, Nakamura T, and Imoto T, J. Biochem., 119, 1086-1093 (1996).

43) Longo MA and Combes DJ, J. Biotechnol., 58, 21-32 (1997).

44) Abuchowski A and Davis FF, Biochim. Biophys. Acta, 578, 4146 (1979).

45) Gennelli M and Strambini GB, Biochim. Biophys. Acta, 1794, 569-576 (2009).

46) Sato H, Adv. Drug Deliv. Rev., 54, 487-504 (2002). 